\title{
Behavioral and Ecological Interactions between Reintroduced Golden Lion Tamarins (Leontopithecus rosalia Linnaeus, 1766) and Introduced Marmosets (Callithrix spp, Linnaeus, 1758) in Brazil's Atlantic Coast Forest Fragments
}

\author{
Carlos Ramon Ruiz-Miranda ${ }^{1,2^{*}}$, Adriana Gomes Affonso ${ }^{1}$, Marcio Marcelo de Morais ${ }^{1,2}$, \\ Carlos Eduardo Verona ${ }^{1}$, Andreia Martins ${ }^{2}$ and Benjamin Beck ${ }^{3}$ \\ ${ }^{1}$ Laboratório de Ciências Ambientais; Universidade Estadual do Norte Fluminense; Av. Alberto Lamego, 2000; \\ Horto; 28013-600; Campos dos Goytacazes - RJ - Brasil. ${ }^{2}$ Associação Mico Leão Dourado; C. P. 109968; 28860- \\ 970; Casimiro de Abreu - RJ - Brasil. ${ }^{3}$ Department of Conservation Biology; National Zoological Park; \\ Smithsonian Institution; 20008; Washington, DC - EUA
}

\begin{abstract}
Marmosets (Callithrix spp.) have been introduced widely in areas within Rio de Janeiro state assigned for the reintroduction of the endangered golden lion tamarin (Leontopithecus rosalia). The objetives of this study were to estimate the marmoset (CM) population in two fragments with reintroduced golden lion tamarin to quantify the association and characterize the interactions between species. The CM population density (0,09 ind/ha) was higher than that of the golden lion tamarin (0,06 ind/ha). The mean association index between tamarins and marmosets varied among groups and seasons (winter $=62 \%$ and summer $=35 \%$ ). During the winter, competition resulted in increases in territorial and foraging behavior when associated with marmosets. Evidence of benefits during the summer was reduced adult vigilance while associated to marmosets. Golden lion tamarins were also observed feeding on gums obtained from tree gouges made by the marmosets. Marmosets represented a threat for the conservation of golden lion tamarins.
\end{abstract}

Key words: Ecology, behavior, golden lion tamarin, common marmoset, invasive species, conservation

\section{INTRODUCTION}

The introduction of exotic or allochthonous species, both accidental and purposeful, has been and is a factor altering native biotas worldwide (Elton, 1958; Daehler and Gordon, 1997; Fritts and Rodda, 1998; Guy et al., 1998; Thomas, 1998). The lack of natural predators, abundance of prey without natural defenses and disturbed habitats, frequently give the invading species an advantage over the native species (Williamson,
1996; Sakai et al., 2001). Introduced species often cause alterations to the habitat or bring diseases that can lead to the extinction of native species (Mack and D' Antonio, 1998). Introduced species can also be competitors. There is no published evidence of any beneficial effects of introduced species on native species of vertebrates (Williamson, 1996). The impact of introduced species can increase in fragmented landscapes (With, 2002), where many species of animals, especially terrestrial vertebrates, are vulnerable to

*Author for correspondence 
extinction because they live in small populations with different degrees of isolation (Meffe and Carroll, 1994; Foose et al., 1995).

Golden lion tamarins (Leontopithecus rosaliamico-leão-GLTs) are endangered primates endemic to the Atlantic coast forest of Brazil (Kleiman et al., 1988; Dietz et al., 1994; Kierulff, 1994). The remaining populations (about 1000 animals) are distributed in a mosaic of forest fragments, of which $60 \%$ are legally protected, $25 \%$ are not protected but in safe areas, and $15 \%$ are in isolated and unprotected small fragments (Kierulff and Oliveira, 1996; AMLD, 2002). There appears to have been considerable genetic losses and genetic structuring cause by fragmentation (Grativol et al., 2001; Grativol, 2003). The conservation program for this species includes protection of wild populations in biological reserves, translocation of wild groups in small and highly degraded areas to biological reserves, and reintroduction of captive-born animals to forests in private farms within the State of Rio de Janeiro (14 farms) (Kierulff and Oliveira, 1994; Kierulff and Oliveira, 1996; Ballou et al., 1998). The population of reintroduced animals (the captive-born animals and their wildborn offspring) represents today $30 \%$ of the golden lion tamarins living in the wild. In the last PHVA (Population and Habitat Viability Analisis), one of the priorities for conservation was the understanding of the factors affecting survival and reproduction after reintroduction (Ballou et al., 1998). One of these factors is the presence of marmosets, Callithrix jacchus and C. penicillata, primates introduced to the State of Rio de Janeiro (Cerqueira et al., 1998; Ruiz-Miranda et al., 2000). The presence of common marmosets (Callithrix jacchus- saguii) was first recorded in the private forest fragments targeted for reintroduction of golden lion tamarins in 1985. The common marmosets are native to northeastern Brazil (Stevenson and Rylands, 1988), and because they were introduced into the state of Rio de Janeiro as the direct result of the illegal wildlife, they are considered an exotic species (Ruiz-Miranda et al., 2000). There is a strong potential for inter-specific competition because the ecology and behavior of these species is similar to that of lion tamarins (Rylands and Faria, 1993). Marmosets and lion tamarins are frugivore-insectivores (Kleiman et al., 1988; Rosenberger, 1992). The marmosets also feed substantially on tree exsudates (mostly gum) (Coimbra-Filho and Mittermeier, 1976; Stevenson and Rylands, 1988; Ferrari, 1993; Kinzey, 1997). The GLTs feed on gums only opportunistically [Peres, 1989].

There are no quantitative data on the population size of the introduced marmosets, on the degree of association between marmosets and tamarins or on the organization of the association. The association between sympatric primates, including the formation of mixed groups, has been documented for Amazonian forest species (Garber, 1988; Heymann, 1990; Peres, 1992; Peres, 1993; Lopes and Ferrari, 1994). In these cases, the associations appear to bring mutual benefits in prey capture (Peres, 1992; Lopes and Ferrari, 1994), predator defense (Peres, 1993) and exploitation and defense of larger territories (Garber, 1988; Heymann, 1990). The genus Leontopithecus and Callitrhix are sympatric only in the Atlantic forest of northern Bahia. At the Una Biological Reserve, L. chrysomelas and C. kuhli associate infrequently (Raboy, 2002).

The objetive of this study was to assess if the presence of Callithrix jacchus or penicillata presented a problem for the conservation of Leontopithecus rosalia. The specific objectives were: (1) estimate the population of marmosets in the largest private forest fragment with reintroduced golden lion tamarins; (2) quantify the degree of association between the species and document any seasonal differences in a large and a small forest fragment; (3) characterize the association, aiming to find behavioral evidence of competition or cooperation between the species. If there were direct competition, then the presence of marmosets would be associated with changes in foraging or territorial behavior. If there were cooperation, then the possible benefits would be reduction in vigilance and exploitation of alternative food sources.

\section{METHODS}

\section{Study site}

The main study site was the Fazenda Rio Vermelho (FRV), Rio Bonito municipality. The secondary study site was the Fazenda do Estreito (FES), municipality of Silva Jardim. Both sites are located in Rio de Janeiro State $\left(42^{\circ} 35^{\prime} 00^{\prime}\right.$ 'W, $22^{\circ} 43^{\prime} 00^{\prime \prime}$ S). The FRV has the largest forest fragment (1000 ha) where tamarins are reintroduced and the largest population of captiveborn reintroduced GLTs. The FES represents one 
of the small forest fragments (30 ha) and has one social group of reintroduced GLTs. Both farms have common marmosets. All GLTs were habituated to human observers and most of the common marmosets were either habituated or semi-habituated (showing no flight from but also no approaches and some avoidance toward humans). The tamarins in these farms were monitored three times per week by field observers of the AMLD. During these visits, the animals were counted, observed for 1-3 hours and supplemented with bananas. At the beginning of the study, there were 10 GLT groups with 65 animals at FRV. GLTs were marked individually with tattoos and hair dye, and at least one animal per group was fitted with a telemetry transmitter.

Four groups from the FRV and the group in the FES were selected for observation. The selection of groups was based on the accessibility of the territories, degree of habituation of GLTs and marmosets and the confirmed presence of the marmosets (Table 1). The groups of marmosets were estimated through observations during the supplementation of food and when following groups of GLTs. These estimates were the minimum number of marmoset groups in the study areas.

\section{Sampling of the population}

As part of the monitoring procedures of the AMLD, reintroduced GLTs were captured twice a year and all individuals marked. Observations by the field team ascertain if any animals were not captured. Capture efforts were directed then toward those individuals. The result was a complete census of the GLTs in both locations. For the marmosets, trapping was done monthly from October 1998 to May 1999. Between 12-16 Tomahawk® traps baited with bananas were positioned in seven of the platforms where GLTs were supplemented and captured. Traps were opened and monitored hourly from 5:00 to 18:00. Capture efforts ended when one marmoset was captured in the platform. This effort never went beyond five consecutive days in a month.

Table 1 - Composition of the golden lion tamarin (GLT) groups studied and a priori determination of occurrence of common marmosets. $\mathrm{N}=$ number of tamarin individuals. Males $=$ number of adult and sub-adult males. Fem $=$ number of adult and sub-adult females, and $\mathrm{CM}=$ estimated groups of marmosets.

\begin{tabular}{l|r|c|c|cc}
\hline \multicolumn{1}{c}{ GLT groups } & N & Males & Fem & Imm & CM \\
\hline Estocolmo (EST) & 13 & 4 & 4 & 5 & 2 \\
Rio Vermelho (RV) & 6 & 2 & 1 & 3 & 1 \\
Triplets (TRI) & 9 & 4 & 2 & 3 & 2 \\
Appenheul (APP) & 6 & 2 & 2 & 2 & 1 \\
Olympia (OLY) & 6 & 2 & 2 & 2 & 1 \\
\hline
\end{tabular}

All marmosets captured were taken to a field laboratory located at $5 \mathrm{~km}$ from the FRV. At the laboratory the marmosets were immobilized with Ketamine, tattooed in the interior of the right thigh, their body condition assessed (by noting pelage condition, teeth wear and wounds), body measures taken, and one animal ( $>350$ grams) in four of the platforms was fitted with a telemetry transmitter. The marmosets were also assigned to age classes (infant, juvenile, sub-adult and reproductive adult) using size, weight (following a growth curve obtained from captive animals), development of teeth and sexual organs as criteria. Animals remained under veterinary supervision until the Ketamine effects wore off and no less than four hours later returned to the capture site. The population density estimate was calculated by dividing the total number of animals marked by the area of forest. This estimate represented the minimum number of marmosets at the time.

\section{Estimates of association and interactions}

Two methods were used: Monitoring and Intense Observations. In Monitoring, the field observers of the AMLD visited each group three times a week year round; each day the GLT groups were observed for one hour. During this time the observers collected data ad libitum (Altmann, 1974; Martin and Bateson, 1986) on presence of marmosets and any behavioral interactions between the species. From this monitoring data, monthly rates of agonistic and affiliative behaviors were calculated by adding all observations seen each day and dividing them by the number of days of observation per month. A monthly index of the presence of marmosets was calculated by adding 
the number of days in which marmosets were observed together with the tamarins, then dividing that number by the number of observation days in that month.

The second method (Intense Observations) consisted of observing the groups for 7-9 days during each Wet season (December to April) and Dry season (July to September) for a total of 32 days in the Wet Season and 25 days in the Dry season. Observations were done from 7:00 to 16:00 with a mean of 7 hours of contact per day per group. The observers collected behavioral data using a scan sampling technique in which, every 20 minutes (Table 2) the presence of marmosets was noted (present or absent) and the behavior of each GLT scored (foraging fruitsinsects; eating-fruits or insects; social; vigilant; territorial; resting-sleeping or not visible). The presence of the marmosets was determined using telemetry equipment and visual observations as follows: (a) Absent: when there was no signal from the telemetry or a weak signal indicating that the animal was far away. To confirm this, a visual inspection was done for 5 minutes within a radius of 30 meters. (b) Present: when the marmosets were either heard or seen from where the GLTs were, or when there was a strong telemetry signal coming from $360^{\circ}$ from the receiver (which in this habitat indicates that the source is within 20 meters from the receiver). In these situations, the observers also approached the telemetry signal or triangulated the signal, or approached the vocalization of the marmosets to confirm the location. These criteria for presence were used because marmosets are difficult to see in this forest, and some marmoset groups were not habituated to humans and individuals would act cryptically.

An association index was calculated for each group in each season as the proportion of the total scans in which the marmosets were present. The differences in association between seasons were tested using a non-parametric Wilcoxon statistic. The behavioral data from scans was used to calculate the relative occurrence of each behavior by age class (adult, sub-adult and immature) when marmosets were present and absent. The frequency of occurrence of each behavior was calculated for each individual within the group as the proportion of observations in each behavioral category divided by the number of scans in which the individual was visible. This individual frequency of occurrence was used to calculate group age class means for each behavior. The sample size was the number of groups multiplied by 3 (the number of age classes). ANOVA was used to test mean differences when the marmosets were present or absent.

Table 2 - Definitions of the behavior recorded during scans sampling of golden lion tamarins

\begin{tabular}{l|l}
\hline \multicolumn{1}{c}{ Behavior } & \multicolumn{1}{c}{ Definition } \\
\hline Insect Foraging & $\begin{array}{l}\text { Searching for insects or small vertebrates in branches, trunks, leaves, tree bark, bromeliads } \\
\text { or ground. } \\
\text { Eating or searching for supplementary food (bananas) in the feeding platforms provided by } \\
\text { the AMLD. }\end{array}$ \\
$\begin{array}{l}\text { Fruit Foraging } \\
\text { Success }\end{array}$ & $\begin{array}{l}\text { Searching for fruits in the camopy or terminal branches or pods. } \\
\text { Time spent eating insetc or prey divided by the the fime foraging for insects or prey. }\end{array}$ \\
Vigilance & $\begin{array}{l}\text { Animal is alert, visual scanning, generally in the periphery of the group, and prone or in the } \\
\text { Sphynx posture (Oliveria et al., 2003). }\end{array}$ \\
Territorial & Animals emiting multiple long calls or clucks, with fights, agonistic displays, scent marking. \\
Eating & Ingesting fruits or prey items. Includes the manipulation of the items. \\
Resting & Animal in prone position in large branches, trunks, with eyes closed or otherwise inactive. \\
Social & Animal interacting socially, including play, grooming, affiliative behavior, nursing.
\end{tabular}

\section{RESULTS}

Two species of marmosets were identified: Callithrix jacchus and C. penicillata. Some individuals seemed to be hybrids of the two species, because they had intermediate tufts in color (grey) and orientation (slopping). The marmosets were more abundant than the tamarins at both locations. At FRV, 90 marmosets were marked from apparently nine social groups, representing a population density of $0.09 \mathrm{ind} / \mathrm{ha}$. At FRV, there were 62 GLTs (density $=0.06$ ind/ha). The territories of GLT groups (TRI, EST) had at least two social groups of marmosets, whereas in groups (APP, RV), there was only one group of marmosets. There was one group of 
marmosets at FES with 9 individuals (Density = $0.32 \mathrm{ind} / \mathrm{ha}$ ), and 8 GLTs (Density $=0.28 \mathrm{ind} / \mathrm{ha}$ ). Eighty-one marmosets were properly aged and sexed. These were distributed into sex-age categories as follows: Females $(\mathrm{N}=42)-24$ adults, 3 sub-adults, 6 juveniles and 7 infants; Males $(\mathrm{N}=$
39)- 28 adults, 3 sub-adults, 6 juveniles and 2 infants. There were 20 females in reproductive phase (10 lactating, 6 pregnant and 4 pregnant and lactating). The adults females (AVG $=374.1$ grams, $\mathrm{SD}=40.2)$ were slightly heavier that the adult males $(\mathrm{AVG}=364.6, \mathrm{SD}=35.8)$.

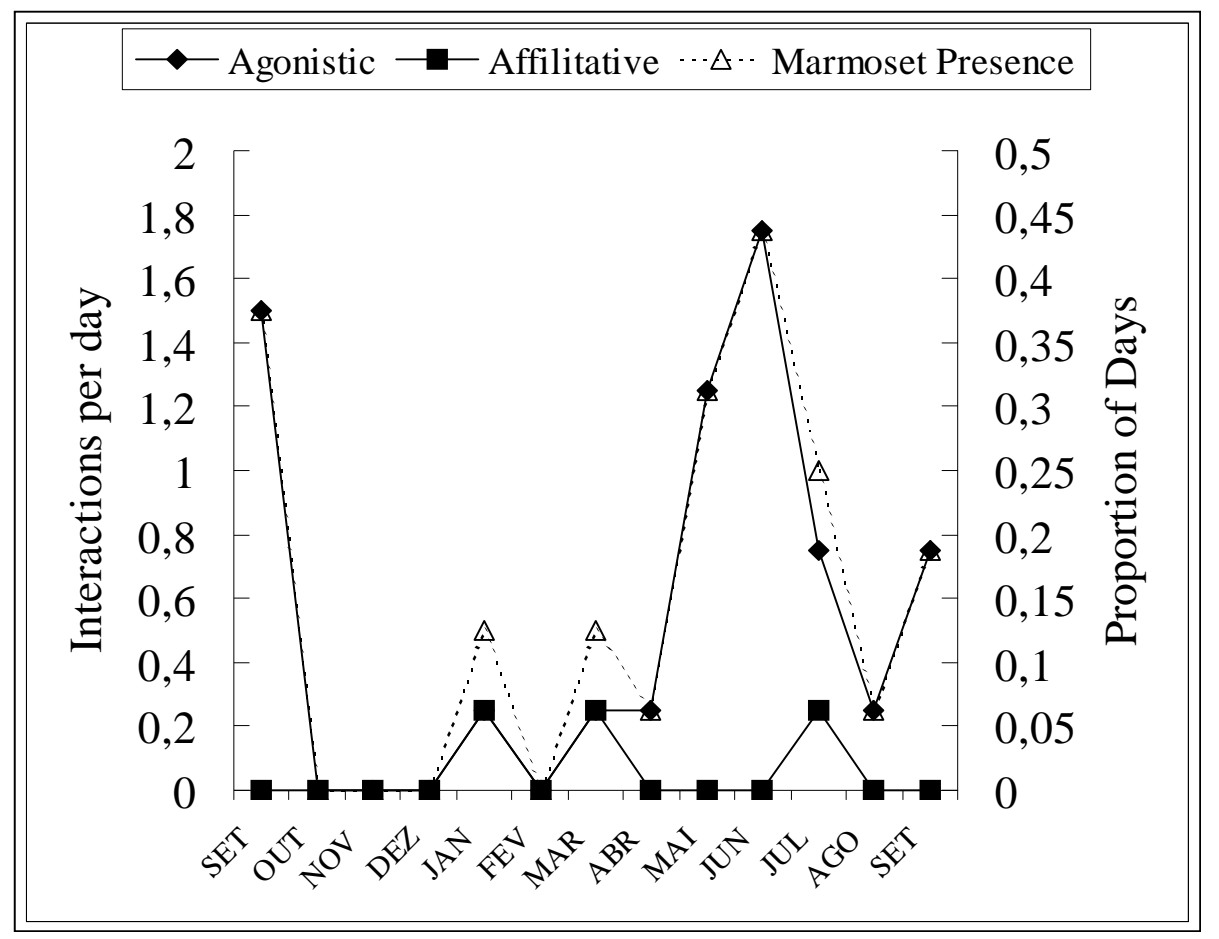

Figure 1 - Mean values of interactions between common marmosets and golden lion tamarins that occurred from September 1998 to September 1999

The monitoring data indicated that the number of days in which the marmosets were observed together with the tamarins increased from April to September (Fig. 1). The scan sample data showed that the degree of association between marmosets and lion tamarins varied among groups of GLTs and seasons (Table 3). The group Estocolmo showed the highest index of association between species, almost twice that of other groups. The indexes of association during the dry season were higher than during the wet season (Wilcoxon's Z= $2.02 ; \mathrm{df}=5 ; \mathrm{p}=0.04)$.

Table 3 - Association index between golden lion tamarins and marmosets during the dry and wet seasons at the Rio Vermelho (FRV) and Estreito Farms (FES).

\begin{tabular}{lcc}
\multicolumn{1}{c}{ Groups (Location) } & Summer & Winter \\
\hline Rio Vermelho (FRV) & 0.32 & 0.40 \\
Appenheul (FRV) & 0.25 & 0.64 \\
Estocolmo (FRV) & 0.68 & 0.81 \\
Triplets (FRV) & 0.17 & 0.63 \\
Olympia (FES) & 0.32 & 0.58 \\
Average & 0.35 & 0.61 \\
\hline
\end{tabular}

The monitoring data showed that the occurrence of agonistic behaviors increased from April to September, whereas the rate of affiliative behaviors was higher from October to March. The scan sampling data showed that the presence of marmosets affected the behavior of lion tamarins 
differently according to season (Table 4), and the groups were also affected differently. During the wet season, the presence of marmosets was associated to a reduction in the foraging of supplemented bananas $(\mathrm{F}=4.66 ; \mathrm{df}=1,11 ; \mathrm{p}=0.05)$, increase in social behavior $(\mathrm{F}=4.80 ; \mathrm{df}=1,11$; $\mathrm{p}=0.05$ ), and a reduction in the vigilance of adult GLTs $(\mathrm{F}=13.08 ; \mathrm{df}=1,7 ; \mathrm{p}=0.01)$. In the dry season, the presence of marmosets was associated to an increase in the time spent foraging fruits $(\mathrm{F}=15.7 ; \mathrm{df}=1,11 ; \mathrm{p}=0.002)$ and the occurrence of territorial behavior $(\mathrm{F}=8.06 ; \mathrm{df}=1,11 ; \mathrm{p}=0.01)$.

\section{DISCUSSION}

The results indicated that introduced Callithrix were a concern for the conservation of golden lion tamarins because (1) the population in the studied areas was equal or larger than that of Leontopithecus, (2) measures of body condition and demography suggest a healthy population of marmosets, (3) marmosets associate significantly with the tamarins, especially in the food supplementation platforms and (4) this association lead to changes in the behavior of the tamarins.

Table 4 - Mean (X); Standard Deviation (sd) and acceptance level (p) for behaviors of golden lion tamarins at Fazenda Rio Vermelho in the absebce and presence of common marmosets during both summer and winter. Data obtained from scan sampling. $\mathrm{ns}=$ not signiticant/ $\mathrm{p}>0.05$; ANOVA repeated measures.; $\mathrm{n}=12$.

\begin{tabular}{|c|c|c|c|c|c|c|c|c|c|c|}
\hline \multirow{3}{*}{ Behavior } & \multicolumn{5}{|c|}{ Summer } & \multicolumn{5}{|c|}{ Winter } \\
\hline & \multicolumn{2}{|c|}{ Absent } & \multicolumn{2}{|c|}{ Present } & \multirow[b]{2}{*}{$\mathbf{p}$} & \multicolumn{2}{|c|}{ Absent } & \multicolumn{2}{|c|}{ Present } & \multirow[b]{2}{*}{$\mathbf{p}$} \\
\hline & $\mathbf{X}$ & sd & $\mathbf{X}$ & sd & & $\mathbf{X}$ & sd & $\mathbf{X}$ & sd & \\
\hline Forage Prey & .14 & .06 & .17 & .04 & ns & .17 & .05 & .17 & .04 & ns \\
\hline Success & .12 & .10 & .11 & .18 & ns & .08 & .13 & .08 & .07 & ns \\
\hline Forage Bananas & .007 & .006 & .002 & .006 & .05 & .02 & .02 & .02 & .01 & ns \\
\hline Forrage Fruits & .02 & .01 & .03 & .03 & ns & .03 & .02 & .07 & .02 & .02 \\
\hline viglance & .09 & .05 & .06 & .05 & ns & .06 & .05 & .07 & .06 & ns \\
\hline Adult vigilance & .12 & .05 & .06 & .05 & .008 & .08 & .04 & .07 & .05 & ns \\
\hline Territorial & .03 & .04 & .02 & .03 & ns & .02 & .03 & .06 & .06 & .01 \\
\hline Resting & .14 & .09 & .13 & .08 & ns & .07 & .08 & .04 & .03 & ns \\
\hline Social & .05 & .03 & .10 & .07 & .05 & .08 & .04 & .10 & .05 & ns \\
\hline
\end{tabular}

The Callithrix observed at FRV were mostly $C$. jacchus and at FES were C. penicillata. However, at both places we observed animals that appeared to be hybrids of these two species. These are species native to northeast (Mata Atlântica) and central (Cerrado) Brazil that invaded the Rio de Janeiro state as a result of introductions by humans. In both locations studied, there were more marmosets than golden lion tamarins.

The body weight of both male and female marmosets at FRV was higher than weights reported weights for $C$. jacchus in captivity and wild within their native home range (Araújo et al., 2000). There were pregnant and lactating females observed in all of the study months, and some of the females had two births per year. Lion tamarins in this location had one birth per year and a seasonal birth period (Verona, 2001). The demographic structure showed a preponderance of reproductively active adults, albeit few young. Strong conclusions were barred because of limitations in sampling and determining age, however, there was evidence of a growing population because the lack of sub-adults appeared to be the result of early sexual maturation, hence the large number of "adults". The lack of neonates could be a sampling problem because adults that carried neonates were "trap shy".

The degree of association between $L$. rosalia and C. jacchus differed between seasons. Seasonal differences (winter > summer) could be the result of higher food abundance during summer (Boinski and Fowler, 1988), when there was a lesser need to extensive search for food and there was less competition for food. The increase in association during winter could be related to scarcity of resources, which caused an increase in the temporal and spatial aspects of searching for food. This could lead to higher overlap in territories between the species. Also, during winter, the supplementation of tamarins with bananas created a clumped food source with lead to higher degree of association and direct competition. 
Even though these indexes of association were high, the species did not form mixed groups, similarly to those that occured in Saguinus, such as Saguinus fuscicollis avilapiresi and Saguinus mystax pileatus in Brazilian Amazônia (Peres, 1992, 1993), Saguinus fuscicollis and Saguinus mystax na Preuvian Amazônia (Garber, 1988; Heymann, 1990), Saguinus fuscicollis weddelli and Callithrix emiliae in Brazilian Amazônia (Lopes and Ferrari, 1994), in which clear benefits in prey capture (Peres, 1992; Lopes and Ferrari, 1994); predator detection and defense (Peres, 1993); exploitation and defense of larger territories (Garber, 1988; Heymann, 1990). The association between $L$. rosalia and $C$. jacchus observed in this study appeared to be more similar to the situation in Una, Bahia, where the golden headed lion tamarin, Leontopithecus chrysomelas is sympatric with Callithrix kuhlii, but associates infrequently and without forming mixed groups (Rylands, 1989).

The association between the golden lion tamarins and the common marmosets showed mostly evidences of competition, with some benefits related to predator detection. Competition was more evident during winter, when resources are scarce. The presence of marmosets during winter led to the tamarins increasing both their foraging of natural fruits and bananas, and their territorial behavior toward the marmosets. The tamarins showed more encounter behavior, with emissions of long calls and increases in agonistic chases and fights. During winter, the marmosets would approach the platforms with supplemental bananas more often, attempted to eat bananas ("steal") while the tamarins chased them away. Agonistic behaviors were initiated by the lion tamarins; suggesting that the presence of the marmosets was not tolerated (Affonso et al., 2004). We interpreted all these observations as evidence of scramble competition. The presence of a competitor with similar diet during times of food scarcity could lead to higher exploitation and defense of resources (Connell, 1983). The tamarins may be following a strategy of "eat before the other eats" or resource depletion, increasing competition and defense. A similar strategy has been suggesting for wild golden lion tamarins at the Poço das Antas reserve to explain why tamarins spent most of their time foraging and patrolling in the periphery of their territories (Peres, 1989).

During wet summer months, the tamarins appeared to tolerate the marmosets and there were indications of benefits from the association. The presence of marmosets was associated to reduction in feeding of bananas, an increase in social behavior by the tamarins and a reduction in the time spent vigilant by adult tamarins (but not the immature). Two benefits from sociality are a reduction in individual vigilance as group size increases and the exploitation of novel food sources (Pulliam, 1973). Predator defense benefits of inter-specific associations have been reported for Saguinus. We observed that when feeding from bananas in the platforms, any alarm calls given by either of the species, resulted in animals from both species locomoting towards nearby branches and initiating search and mobbing behaviors. Perhaps, the abundance of resources together with less time looking for predators, allowed for increases in social behaviors among the tamarins. However, predator related benefits could not be shared equally between the species. Even though vigilance was reduced and both species emitted alarm calls, the marmosets may receive higher benefits because its more cryptic coloration would render it less detectable by an approaching bird or mammalian predator. At this site, predation events observed include attacks by birds of prey and snakes (Stafford et al., 1995).

One possible benefit of the association for the tamarins would be the exploitation of novel food sources. There was the possibility that captiveborn reintroduced tamarins would feed on the gums trees harvested by the marmosets. This potentially newly available food source could enrich tamarins diet with calcium and polysaccharides, both important resources for reproductive females and young. Tamarins naturally take gums opportunistically from tree nodes and wounds (Coimbra-Filho and Mittermeier, 1976). The tree holes made by marmosets occupy the entire tree trunk and are more common during winter. However, tamarins were observed to feed on marmoset gum trees infrequently. It is unknown if the use of gums by tamarins would be detrimental to the marmosets, as was the case for Callithrix emiliae in Amazônia (Lopes and Ferrari, 1994). On occasion, when groups of Saguinus fuscicollis weddelli and Callithrix emiliae were traveling together, Saguinus fuscicollis weddelli would reach gun trees first and deplete them before $C$. emiliae would arrive. Before asserting that marmosets brought some benefits to the endangered species, it 
would be necessary to obtain more information on the use of gums by tamarins, whether it was consumed only opportunistically and whether it was digested. Marmosets have dietary adaptations for processing these gums (Power, 1991; Power and Oftedal, 1996), and the tamarins might not be able to take advantage of gums in the form harvested by marmosets.

Notwithstanding these trends, there was evidence that the interactions between the species were different for the tamarins groups. The degree of association between species differed among groups of tamarins. These differences could be related to demographic characteristics of the tamarins groups (group size; age structure) or to the number of marmosets in the vicinity, or to habitat characteristics (more resources). The tamarins group that showed the highest index of association both in winter $(81 \%)$ and summer (68\%) was the largest group at FRV with 13 animals (including 6 sub-adults and 4 immature) and with the presence of at least two marmoset groups. In this tamarin group we observed play bouts with the marmosets that went uninterrupted for over two hours (Oliveira et al., 2003). Moreover, there is an abandoned orchard (with jaca -Artocarpus spp., jambo-Syzygium malaccense, cashew trees-Anacardium occidentale) that attracts both species. Another possibility is that the higher degree of association in larger social groups of tamarins is the result of larger territories, and therefore a higher probability of encountering marmosets. This is unlikely because group size is not a determinant of territory size in golden lion tamarins (Procópio de Olivera, 2003). The second highest association index was at the FES, a fragment with less than 30 ha. Here food is scarce during some times of the year and the supplementation with bananas results in "clumped" resources. Also, in this group, as with the group Appenheul at FRV, the sleeping hole of the marmosets in only meters away from that of the tamarins and from the supplemental feeding platform. Future research could consider the relationship between territory size, resource distribution and interactions with marmosets.

The use of two methods of data collection provided useful information for future monitoring of these interactions. Because the results of the two methods were qualitatively similar, we suggest that one-hour periods of observation repeated at least 5 days per month would provide enough data to assess relative changes or levels of interactions between these species. These kinds of relative data could be used by teams monitoring species interactions after management actions such as re-forestation, recuperation of degraded fragments, building of corridors, changes in levels of supplementation or changes in the populations of either species. These data should be collected from groups that reflect the variation in social systems or ecological conditions of the region and species under study.

From these combined data, we concluded that marmosets were an important factor for the conservation of lion tamarins. Both at FRV, the largest fragment with reintroduced lion tamarins, and at FES, the marmosets were surviving and reproducing well and had the potential of being a serious competitor for resources for the tamarins. There is a considerable association between the species and this association lead to changes in the behavior of the tamarins that suggest direct competition for resources during the winter months. The possible benefits to the tamarins of access to gum resources appeared to be insignificant. Moreover, the apparently high reproductive potential of the marmosets, together with the indiscriminate releases related to the wildlife trade, could make the introduced species likely to colonize other fragments where tamarins could be reintroduced or translocated. Survey studies revealed that common marmosets were widespread and perhaps dispersing throughout the state of Rio de Janeiro (Cerqueira et al., 1998; Ruiz-Miranda et al., 2000). Before any control measures can be exerted over the marmosets, more research would be needed on niche overlap, marmoset population trends and dispersal capabilities in the fragmented landscape of the region.

\section{ACKNOWLEDGEMENTS}

This study received logistic support from the Associação Mico Leão Dourado, IBAMAInstituto Brasileiro de Meio Ambiente e dos Recursos Naturais Renováveis and the UENFUniversidade Estadual Norte Fluminense. Financial support came from PRONABIO/PROBIO/MMA with funds from BIRD/GEF, Frankfurt Zoological Society Fund for Threatened Species, IESP program from the National Zoological Park of the Smithsonian Institution, WWF- World Wild Fund for Nature- 
Brazil and FAPERJ. Adriana Affonso was supported by an undergraduate fellowship from the UENF. We thank the students (Agnes Velloso, Vera Sabatini, Guilherme Faria, Amilcar Fraga, Fabrício Alvim, Claudia R. de Oliveira, Andressa Sales Coelho, Alexandre Túlio Amaral Nascimento, Sérgio Bonadiman, Marciane e Alessandra,) and AMLD field assistants (Nelsinho, Arléia, Paulo, Zamã, William, Javez e Paulo César, Ezequiel Moraes) that helped collect data. We are grateful to the owners of the farms in which the study was conducted.

\section{RESUMO}

Callithrix jacchus e spp (micos estrela) tem sido introduzido no estado do Rio de Janeiro em áreas designadas para a reintrodução do Leontopithecus rosalia (mico leão dourado). Os objetivos deste estudo foram estimar a população de sagüis em dois fragmentos particulares, e caracterizar a interação entre as espécies. A densidade de sagüis $(0.09 \mathrm{a} / \mathrm{ha})$ foi maior que a de mico-leão $(0.06$ a/ha). O grau de associação entre mico-leão e o sagüi variou entre grupos e estações do ano (inverno $=61 \%$, verão $=35 \%$ ). Foram observados sinais de competição durante o inverno quando a presença do mico estrela está associada a mudanças no forrageio do mico-leão e aumento de comportamentos territoriais. No verão, sinais de benefícios foram uma diminuição da vigilância por parte dos adultos de micos leões. Além disso, os micos leões foram observados se alimentando de goma proveniente dos buracos feitos pelos micos estrela. Estes resultados sugerem que o mico estrela é uma ameaça para a conservação do micoleão, no entanto.

\section{REFERENCES}

Affonso, A. G.; Ruiz-Miranda, C. R. and Beck, B. B. (2004), Interações ecológicas entre mico leão dourado (Leontopithecus rosalia Linnaeus, 1758) reintroduzido e mico estrela (Callithrix jacchus Linnaeus, 1758) introduzido em fragmentos de mata atlântica, RJ. In: Mendes, S. L. and Chiarello A. G. A primatologia no Brasil. Santa Teresa, RJ. v. 8. [in press].

Affonso, A. G. (2000), Interações Ecológicas entre mico leão dourado (Leontopithecus rosalia Linnaeus, 1766) reintroduzido e mico estrela (Callithrix jacchus Linnaeus, 1758) introduzido em fragmentos de mata
Atlântica, RJ. Monografia de Bacharelado degree, Universidade Estadual do Norte Fluminense. Campos dos Goytacazes. 38.

Altmann, J. (1974), Observational study of behaviour: sampling methods. Behaviour, 49 : (3,4), 227-265.

Amld (1998), Relatório annual da Associação Mico Leão Dourado (Annual report of the Golden Lion Tamarin Association), Associação Mico Leão Dourado/Golden Lion Tamarin Association.

Araújo, A.; Arruda, M. F.; Alencar, A. I.; Albuquerque, F.; Nascimento, M. C. and Yamamoto, M. E. (2000), Body weight of wild and captive common marmosets (Callithrix jacchus). International Journal of Primatology, 21 : (2), 317-324.

Ballou, J. D.; Lacy, R. C.; Kleiman, D. G.; Rylands, A. and Ellis, S. (1998), Leontopithecus II. Final Report: The second population and habitat viability assessment for lion tamarins (Leontopithecus), Held 20-22 May, 1997, Belo Horizonte, Brazil. Belo Horizonte, Brazil, International Committee for the Conservation of Lion Tamarins.

Beck, B. B.; Castro, M. I.; Stoinsky, T. S. and Ballou, J. D. (2002), The efects of prerelease environments and postrelease management on survivorship in reintroduced golden lion tamarins. In: Kleiman, D. G. and Rylands, A. B. (Eds.). Lion Tamarins- Biology and Conservation. Washington: Smithsonian Institution Press. pp. 283-300.

Beck, B. B.; Kleiman, D. G.; Dietz, J. M.; Castro, I.; Carvalho, C.; Martins, A. and Retterberg-Beck, B. (1991), Losses and reproduction in reintroduced golden lion tamarins, Leontopithecus rosalia. Dodo, 27, 50-61.

Boinski, S. and Fowler, N. F. (1988), Seasonal patterns in a tropical lowland forest. Biotropica, 21, 223-234.

Cerqueira, R.; Marroig, G. and Pinder, L. (1998), Marmosets and lion tamarins distribution (Callitrichidae, Primates) in Rio de Janeiro State, south-eastern Brazil. Mammalia, 62 : (2), 213-226.

Coimbra-Filho, A. and Mittermeier, R. A. (1976), Exudate-eating and tree-gouging in marmosets. Nature, 262 : (5569), 630.

Connell, J. H. (1983), On the prevalence and relative importance of interspecific competition: evidence from field experiments. The American Naturalist, 122 : (5), 661-696.

Daehler, C. and Gordon, D. R. (1997), To introduce or not to introduce: trade-offs of non-indigenous organisms. Trends on Ecology and Evolution, 12 : (11), 424-425.

Dietz, J.; Dietz, L. and Nagagata, E. (1994), The effective use of flagship species for conservation of biodiversity: the example ol lion tanarins in Brazil. In: Olney, P. J. S.; Mace, G. M. and Feistner, A. T. C. (Eds.). Creative conservation: interactive management of wild and captive animals. London, Chapman and Hall. pp. 32-49.

Elton, C. (1958), Ecology of invasions by animals and 
plants. Methuen and Co., London.

Ferrari, S. F. (1993), Ecological differentiation in the Callitrichidae. In: Rylands, A. B. (Ed.). Marmosets and Tamarins: Systematics, behaviour, and ecology. Oxford: Oxford University Press. pp. 314-328.

Foose, T. J.; De Boer, L.; Seal, U. S. and Lande, R. (1995), Conservation management strategies based on viable populations. In: Ballou, J. D.; Gilpin, M. and Foose, T. J. (Eds.). Population management for survival and recovery: analytical methods and strategies in small population conservation. New York: Columbia University Press. pp. 273-294.

Fritts, T. H. and Rodda, G. R. (1998), The Role of Introduced Species in the degradation of island acosystems: A case history of Guam. Ann. Rev. Ecol. Syst., 29, 113-140.

Garber, P. A. (1988), Diet, foraging patterns, and resource defense in a mixed species troop of Saguinus mystax and Saguinus fuscicollis in amazonian Peru. Behaviour, 105 : (1-2), 18-34.

Grativol, A. (2003), DNA antigo e genética da conservação do mico leão dourado (Leontopithecus rosalia): estrutura genética em duas escalas de tempo e sua relação com a fragmentação da mata Atlântica. DSc- Biociências degree, Universidade Estadual Norte Fluminense. Campos dos goytacazes.

Grativol, A.; Ballou, J. D. and Fleischer, R. C. (2001), Microsatellite variation within and among recently fragmented populations of the golden lion tamarin (Leontopithecus rosalia). Conservation Genetics, 2, 1-9.

Guy, P. L.; Webster, D. E.; Davis, L. and Foster, R. L. S. (1998), Pests of non indigenous organisms hidden costs of introduction. Trends in Ecology and Evolution, 13, 111.

Heymann, E. W. (1990), Interspecific relations in a mixed species troop of moustached tamarins, Saguinus mystax, and saddle back tamarins, Saguinus fuscicollis (Platyrrhini: Callitrichidae), at the Rio Blanco, Peruvian Amazonia. American Journal of Primatology, 21, 115-127.

Kierulff, C. M. and Oliveira, P. P. (1996), Re-assessing the status and conservation of the golden lion tamarin, Leontopithecus rosalia, in the wild. Dodo. Jersey Wildlife Preservation Trusts, 32, 98-115.

Kierulff, M. C. (1994), Avaliação das populações selvagens de micos leões dourados, Leontopithecus rosalia, e proposta de estrategia para sua conservação. MSc degree, Universidade Federal de Minas Gerais. Belo Horizonte.

Kierulff, M. C. M. and Oliveira, P. P. D. (1994), Habitat preservation and the translocation of threatened groups of Golden Lion Tamarins, Leontopithecus rosalia. Neotropical Primates, 2, 15-17.

Kinzey, W. G. (1997), New World Primates: ecology, evolution and behavior. New York: Aldine de Gruyter.

Kleiman, D. G.; Hoage, R. J. and Green, K. M. (1988),
The lion tamarins, Genus Leontopithecus. In: Mittermeier, R. A.; Coimbra-Filho, A. F. and Fonseca, G. A. B. (Eds.). Ecology and behavior of neotropical primates. World Wildlife Fund, New York, 2, 299-347.

Lopes, M. A. and Ferrari, S. F. (1994), Foraging behavior of a tamarin group (Saguinus fuscicollis weddelli) and interactions with marmosets (Callithrix emiliae). International Journal of Primatology, 15 : (3), 373-387.

Mack, M. C. and D'Antonio, C. M. (1998), Impacts of biological invasions on disturbance regimes. Trends on Ecology and Evolution, 13 : (5), 195-197.

Martin, P. and Bateson, P. (1986), Measuring Behaviour. New York: Cambridge University Press.

Meffe, G. K. and Carroll, C. R. (1994), Principles of Conservation Biology. Sunderland: Sinauer Associateds, Inc.

Oliveira, C. R.; Ruiz-Miranda, C. R.; Kleiman, D. G. and Beck, B. B. (2003), Play behavior in juvenile golden lion tamarins (Callitrichidae: Primates): organization in relation to costs. Ethology, 109, 593-612.

Peres, C. (1989), Exudate-eating by wild golden lion tamarins, Leontopithecus rosalia. Biotropica, 21 : (3), 287-288.

Peres, C. A. (1992), Prey-capture benefits in a mixedspecies group of Amazonian tamarins, Saguinus fuscicollis and S. mystax. Behavioral Ecology and Sociobiology, 31, 339-347.

Peres, C. A. (1993), Anti predation benefits in a mixed species group of Amazonian tamarins. Folia Primatologica, 61, 61-76.

Power, M. L. (1991), Digestive function, energy intake and the digestive response to dietary gum in captive callitrichids. Doctoral dissertation degree, University of California. Berkeley.

Power, M. L. and Oftedal, O. T. (1996), Differences among captive Callitrichids in the digestive responses to dietary gum. American Journal of Primatology, 40, 131-144.

Procópio De Oliveira, P. (2003), Ecologia alimentar, dieta e área de uso de micos leões dourados translocados e sua relação com a distribuição espacial e temporal de recursos alimentares na Reserva Biológica União, RJ. Doctorate in Science degree, Universidade Federal de Minas Gerais. Belo Horizonte.

Pulliam, H. R. (1973), On the advantages of flocking. Journal of Theoretical Biology, 38, 419-422.

Raboy, B. E. (2002), The ecology and behavior of wild golden-headed lion tamarins, Leontopithecus chrysomelas. PH.D. degree, University of Maryland. Collegue Park.

Rosenberger, A. L. (1992), Evolution of feeding niches in New World monkeys. American Journal of Physical Anthropology, 88, 525-562.

Ruiz-Miranda, C. R.; Affonso, A. G.; Martins, A. and Beck, B. B. (2000), Distribuição do sagüi (Callithirx 
jacchus) nas áreas de ocorrência do mico leão dourado no Estado de Rio de Janeiro. Neotropical Primates, 8 : (3), 98-101.

Rylands, A. B. (1989), Sympatric Brazilian callitrichids: the black tufted-ear marmoset, Callithrix kuhli, and the golden-headed lion tamarin, Leontopithecus chrysomelas. Journal of Human Evolution, 18, 679-695.

Rylands, A. B. and Faria, D. S. (1993), Habitats, feeding ecology, and homerange size in the genus Callithrix. In: Rylands, A. B. (Ed.). Marmosets and tamarins: systematics, behaviour, and ecology. Oxford: Oxford University Press. pp. 262-272.

Sakai, A. K.; Allendorf, F. W.; Holt, J. S.; Lodge, D. M.; Molofsky, J.; With, K. A.; Baughman, S.; Cabin, R. J.; Cohen, J. E.; Ellstrand, N. C.; Mccauley, D. E.; O'neil, P.; Parker, I. M.; Thompson, J. N. and Weller, S. G. (2001), The population biology of invasive species. Ann. Rev. Ecol. Syst., 32, 305-332.

Schoener, T. (1974), Resource partitioning in ecological communities. Science, 185, 27-39.

Stafford, B. J. and Ferreira, F. M. (1995), Predation attempts on callitrichids in the Atlantic coastal rain forest of Brazil. Folia Primatologica, 65, 229-233.

Stevenson, M. F. and Rylands, A. B. (1988), The Marmosets, Genus Callithrix. In: Mittermeier, R. A.; Coimbra-Filho, A. F. and Fonseca, G. A. B. (Eds.). Ecology and behavior of neotropical primates. World Wildlife Fund, New York, 2, 131-222.

Thomas, M. B. (1998), Biocontrol: risky but necessary? Trends in Ecology and Evolution, 13, 325-328.

Verona, C. E. S. (2001), Avaliação da condição física versus custos de reprodução e lactação em fêmeas de Callithrix jacchus e Leontopithecus rosalia selvagens. MSc. degree, Universidade Estadual Norte Fluminense. Campos. pp. 79.

Williamson, M. (1996), Biological Invasions. London: Chapman and Hall.

With, K. A. (2002), The landscape ecology of invasive spread. Conservation Biology, 16 : (5), 1192-1203. 